\title{
The Association Between Smartphone Use and Breast Cancer Risk Among Taiwanese Women: A Case-Control Study [Response to Letter]
}

This article was published in the following Dove Press journal: Cancer Management and Research

\author{
Ya-Wen Shih' \\ Hsiu-Ting Tsai (iD) ${ }^{1,2}$ \\ 'School of Nursing, College of Nursing, \\ Taipei Medical University, Taipei, Taiwan; \\ ${ }^{2}$ Post-Baccalaureate Program in Nursing, \\ College of Nursing, Taipei Medical \\ University, Taipei, Taiwan
}

\section{Dear editor}

We thanks Dr SMJ Mortazavi for interest in our recent publication. ${ }^{1}$

Regarding to his first comments on "smartphone blue light filter". We agree with his opinion in terms of blue light suppressing the secretion of melatonin, which possibly causes circadian rhythm disruption. ${ }^{2}$ Though most applications are available in modern smartphones, people are mostly not aware of the dangers of the blue light, hence they usually do not apply the blue light filter for protection, especially in Taiwan and China. ${ }^{3}$ That is why we did not consider this factor would affect our result. All participants stand on the same baseline.

The second concern was about the control of environmental light before bedtime. The environmental lights' exposure intensity and frequency vary from the individual and complicated causal mechanisms in a naturalistic setting. Notably, Lin et al, discovered smartphone use has a mediator effect of circadian rhythm delay with daily and bedtime pre-sleep. They indicated that using a smartphone before bedtime mediated delayed circadian rhythm and reduced the total sleep time. ${ }^{4}$ Furthermore, Chang et al also demonstrated that using the light-emitting device before bedtime increased the risk of delayed sleep-phase disorder and sleep-onset insomnia. ${ }^{5}$ In addition it was reported that as smartphone light can suppress melatonin production, which is not only a sleeppromoting hormone, but also plays an important role in inhibiting the release of estrogen, resulting in a propensity for breast cancer. ${ }^{4,5}$ These illustrated that the light emitted by smartphones could be harmful to human well-being.

Thank you for your contributions and comments. This is a very important health issue, as smartphones become indispensable to life gradually, it already changes in the living styles of human beings. No study has investigated the relationship between smartphone use and breast cancer. This case-control study purposely investigated the relationship between smartphone use and breast cancer risk. However, the findings of this research are that excessive smartphone use significantly increased the risk of breast cancer. Particularly for participants with smartphone addiction, close distance between breasts and smartphones, and the habit of smartphone use before bedtime.

Therefore, we hope these findings may provide a basis for further scientific research and we will consider these confounding factors you mentioned in our future research.
Correspondence: Hsiu-Ting Tsa College of Nursing, Taipei Medical University, No. 250 Wu-Xing Street, Taipei

I I03I, Taiwan, Republic of China

Tel +886-2-2736-I66I ext. 6330

Fax +886-2-2736-1664

Email hsiuting@tmu.edu.tw 


\section{Disclosure}

The authors report no conflicts of interest in this communication.

\section{References}

1. Shih YW, Hung CS, Huang CC, et al. The association between smartphone use and breast cancer risk among Taiwanese women: a case-control study. Cancer Manag Res. 2020;12:10799-10807. doi:10.2147/CMAR.S267415

2. Mortazavi SAR, Parhoodeh S, Hosseini MA, et al. Blocking shortwavelength component of the visible light emitted by smartphones' screens improves human sleep quality. J Biomed Phys Eng. 2018;8 (4Dec):375-380. doi:10.31661/jbpe.v8i4Dec.647
3. Shen Q, Xu L, Jiang Y, Zheng R, Zhang Y. Survey and statistical analysis of Hangzhou citizens' awareness of harmful blue light and consciousness of protection against blue light. J Phys Conf Ser. 2020;1616:012074.

4. Lin YH, Wong BY, Lin SH, Chiu YC, Pan YC, Lee YH. Development of a mobile application (App) to delineate "digital chronotype" and the effects of delayed chronotype by bedtime smartphone use. $J$ Psychiatr Res. 2019;110:9-15. doi:10.1016/j. jpsychires.2018.12.012

5. Chang AM, Aeschbach D, Duffy JF, Czeisler CA. Evening use of light-emitting eReaders negatively affects sleep, circadian timing, and next-morning alertness. Proc Natl Acad Sci USA. 2015;112 (4):1232-1237. doi:10.1073/pnas.1418490112

Dove Medical Press encourages responsible, free and frank academic debate. The content of the Cancer Management and Research 'letters to the editor' section does not necessarily represent the views of Dove Medical Press, its officers, agents, employees, related entities or the Cancer Management and Research editors. While all reasonable steps have been taken to confirm the content of each letter, Dove Medical Press accepts no liability in respect of the content of any letter, nor is it responsible for the content and accuracy of any letter to the editor.

Cancer Management and Research

Dovepress

\section{Publish your work in this journal}

Cancer Management and Research is an international, peer-reviewed open access journal focusing on cancer research and the optimal use of preventative and integrated treatment interventions to achieve improved outcomes, enhanced survival and quality of life for the cancer patient.
The manuscript management system is completely online and includes a very quick and fair peer-review system, which is all easy to use. Visit http://www.dovepress.com/testimonials.php to read real quotes from published authors. 